\title{
MONITORING OF DRINKING WATER QUALITY BY BACTERIAL INDICA- TORS AND TRIAL FOR DETECTION
}

\author{
${ }^{1}$ Farrag a ${ }^{\text {A.A }}{ }^{2}$ Khalil a ${ }^{\text {A.M }}$ and ${ }^{3}$ El.Bahnasy ${ }^{\text {b}}$ M.A. \\ $a$ - Al-Azhar University. Faculty of science, microbiology Department.Nassar City, Cairo, Egypt. \\ b- Water and waste Water Company .Central lab, El-Gharbia Gavernate.Tanta, Egypt.
}

\begin{abstract}
In this study eight water samples were collected from three plants, (Al-Arida plant, (3 sample),Shobra-blola plant (3 sample), and Meet-maemon plant (2 sample) from AL-Gharbia, Egypt. The results showed that the seasonal variation in heterotrophic and streptococcus bacteria showed the microbial prevalence in raw water of Al-Arida plant, but not detected in filtrated water. On the other hand,both of total and fecal Coliform bacteria showed microbial prevalence in raw water of AlArida plant mean while disappeared in filtrated water. However, Shobra-blola plant and Meet-maemon plant showed seasonal variation in heterotrophic and streptococcus bacteria in a permissible limits. Amazingly new media (Lauryl tryptose broth with mug) has the ability to detect the indicator bacteria in only $24 \mathrm{hr}(\mathrm{s})$. versus conventional methods as Most Probable Number $(M P N)$ and membrane filtration (MF). Accordingly, the pollution level have been indicated as water quality index, (WQI) for all annual seasons which its arrangement was in descending order as, Winter $<$ Autumn $<$ Spring $<$ Summer respectively. Also, the highest Pollution levels was in winter season as compared with other seasons. This phenomenon may be attributed to the accumulation of wastes of drains which is accompanied by winter stagnant period while lowers water level in River Nile leading to an increase in pollutants loaded and decreased in diluted levels.
\end{abstract}

Key words: Drinking water, bacterial indicators, Detection trials, total \& fecal Coliform bacteria.

\section{INTRODUCTION}

The World Health Organization estimates that Diarrhea caused by inadequate drinking water, sanitation and hand hygiene kills an estimated 842,000 people every year globally or approximately 2,300 people per day) Tropical Medicine and International Health, 2014 (.750 million people around the world lack access to safe water; approximately one in nine people, more than twice the population of the United States lives without access to safe water)World Health Organization and United States Census Bureau Estimates 2014). 82\% of those who lack access to improved water live in rural areas, while just $18 \%$ live in urban areas)World Health Organization and UNICEF Joint Monitoring Programme 2014).

The lack of freshwater is likely to be one of the most critical natural resource issues facing people in the next 50 years. The world's population is expanding rapidly, yet our supplies of freshwater are not, placing greater demand on our water resources, this makes it even more important that the remaining freshwater we have is kept safe and clean (Environmental Protection Agency, 1995).
The Nile River is the principal freshwater resource for Egyptians and represents more than 97\% of Egyptian water resources (Korium and Toufeek, 2008). Globally, industrial waste water represents the main source of water pollution. The uprising increase in modern industries, agriculture urbanization, tourism and human activities are the main sources for chemical pollution to both, aquatic environment and its coexisting ecosystems (Gunkel et al., 2007). Heavy metals are persistent contaminants in the environment causing serious illness in fish, animals and human. Regionally, industrial and agricultural runoffs are considered the primary source of metal poisoning to fish and other aquatic animals in Egypt (Eissa et al., 2013)

Contamination of water is a serious environmental problem as it adversely affects the human health and the biodiversity in the aquatic ecosystem. The use of indicator bacteria such as fecal Coliforms (FC) and fecal streptococci (FS) for assessment of fecal pollution and possible water quality deterioration in fresh water sources is widely used (AWWA and WEF, 2005).

Liquid water is a highly versatile material, although it is formed from the tiniest of molecules, it can shape and control bio molecules. The hy- 
drogen-bonding properties of water are crucial to this versatility, as they allow water to execute an intricate three-dimensional 'ballet', exchanging partners while retaining complex order and enduring effects. Water can generate small active clusters and macroscopic assemblies, which can both transmit information on different scales. (Nature Reviews Molecular, 2006). Different bacterial genera in the water of the River Nile at Egypt is due to direct contamination caused by human activities and indirect effect by ecological disturbances. Bacteria may enter the distribution system through the failure to disinfect water or maintain a proper disinfection residual; low pipeline water pressure; intermittent service; excessive network leakages; corrosion of parts and inadequate sewage disposal (Narasimhan, 2008). One of the most important factors of water pollution is the microbial contamination; especially with pathogenic microorganisms. Enteric pathogens are typically responsible for waterborne sickness (WWAP, 2009)

\section{MATERIALS \&METHODS}

\section{SAMPLING LOCATIONS}

Eight water sample(s) were collect from El-Gharbia area for each season starting from $21 / 12 / 2012$ to $21 / 3 / 2013$ "winter season" also Another eight sample were collect from $21 / 3 / 2013$ to $21 / 6 / 2013$ "spring seasons" " then from $21 / 6 / 2013$ to $21 / 9 / 2013$ "summer season and lastly "autumn season" from 21/9/2013 to 21/12/2013.

El-Gharbia samples were collected from (out, in and distribution network system) plant. Selected three plants (Al-arida plant, shobra blola plant and meet maemon plant). The El-Arida plant (filirtrated water plant from the Nile "raw water"), the Shobra-blola plant called (treatment water plant from well) and the meet maemon plant (without treatment) the water direct to the network distribution.

The bacteria present in this study according to family Enterobacteriaceae.

\section{SAMPLING}

The water samples were collected in clean, sterile and transparent polyethylene bottles without any dechlorinating agent for the inorganic analysis and sodium thiosulfate $(0.1 \mathrm{ml}$ of $3 \%$ $\mathrm{Na} 2 \mathrm{~S} 2 \mathrm{O} 3$ ) for the microbiological analysis to neutralize residual chlorine present in tap water.

For analysis heavy metals bottle used are made of autoclavable plastic ( capacity $0.5 \mathrm{~L}$ ) and acidify the sample to $\mathrm{pH}<2$ using $2 \mathrm{ml}$ very pure nitric acid then stored in a refrigerator (APHA, 2005).

\section{BACTERIAL IDENTIFICATION:}

The bacterial isolates exposed to different physic \&biochemical testes then conformed identification by using Analytical profile Index(API Rapid 20E Kit) used for Enterobacteriaceae (Barry and Badal,1979)

\section{WATER ANALYSIS}

The bacteriological, physical and chemical parameters of water samples WERE estimated according to the standard methods for the examination of water and wastewater (APHA, 2005) as well as purification and confirmed identification of waterborne indicator bacteria according to API.

Total organic carbon (TOC) measurement by using sievers 5310 Instrument ((APHA, 2005).

\section{SAMPLING AND STORAGE:}

Collected and stored samples were done in glass bottle as protection from sunlight and sealed with Teflon (TFE) septum.

Before use bottles washed with acid (example HCL) and bake at $250^{\circ} \mathrm{c}$ for at least $1 \mathrm{hr}$.

Washing of un- cleaned Teflon (TFE) septa with detergent rinse repeatedly with organic free water.

Check performance of new or cleaned septa by running appropriate blanks.

Keeping the bottles in a place free from organic contamination

Rinse bottle with sample before filling. When sample collected.

Preserving sample that cannot be examined immediately by holding at $4{ }^{\circ} \mathrm{C}$ with minimal exposure to light and atmosphere acidification with phosphoric or sulphoric acid to $\mathrm{PH} \leq 2$ at the time of collection is especially desirable for unstable samples and may be used on all sam- 
ples: acid preservation however invalidates any inorganic carbon determination on the samples APHA,(2005).

\section{RESULTS}

Table (1) showing that the seasonal variation of chemicals and biological analysis of raw water (El-Arida plant) during four seasons. It was observed that the seasonal variations in turbidity concentration were found in the ranges of, (8.6, 11,10 and 9 NTU) during winter, spring, summer and autumn respectively. The highest value of turbidity (11 NTU) was found in the spring season while the lowest value of turbidity (8.6 NTU) was found in the winter season.

Regarding the mean value of seasonal variations in temperature concentration of water was found in the ranges of, $\left(19.3,27,29\right.$ and $\left.21{ }^{\circ} \mathrm{C}\right)$ during winter, spring, summer and autumn respectively. it was found that highest temperature value was $\left(29^{\circ} \mathrm{C}\right)$ in summer season while the lowest value was found in winter season at $\left(19.3^{\circ} \mathrm{C}\right)$.

There was no difference in $\mathrm{pH}$ in the four seasons as showed in table (1)

The seasonal variation of Electric Conductivity $(\mathrm{EC})(\mu \mathrm{s} / \mathrm{cm})$ concentration was found in the ranges of $(403.5,305,293$ and $310 \mu \mathrm{s} / \mathrm{cm})$ during winter, spring, summer and autumn respectively. The maximum concentration was recorded in the winter $(403.5 \mu \mathrm{s} / \mathrm{cm})$ and the minimum concentration was occurred in the summer (293 $\mu \mathrm{s} / \mathrm{cm})$.

The seasonal variation of total dissolved solids concentration at $\left(120^{\circ} \mathrm{C}\right)$ was found in the ranges of, (201, 154, 146 and $212 \mathrm{mg} / \mathrm{l})$ during winter, spring, summer and autumn respectively. The maximum concentration was occurred in the autumn as $(212.5 \mathrm{mg} / \mathrm{l})$ while the minimum concentration was occurred in the summer as, (146 $\mathrm{mg} / \mathrm{l})$.

The seasonal variation of total organic carbon (TOC) concentration was found in the ranges of $(5.69,4.95,4.6$ and $4.92 \mathrm{mg} / \mathrm{l})$ during winter, spring, summer and autumn respectively. The maximum concentration was recorded in the winter as $(5.69 \mathrm{mg} / \mathrm{l})$ and the minimum concentration was occurred in the summer as $(4.6 \mathrm{mg} / \mathrm{l})$.
This table presented that seasonal variations of the total bacterial count were found in the ranges of $(3148,3293,2712$ and 2703 colony forming unit) during winter, spring, summer and autumn respectively. The maximum concentration was recorded in the spring as (3293 cfu) and the minimum concentration was occurred in the autumn as (2703 cfu).

The seasonal variation of total Coliform count was found in the ranges of $(66,39,33$ and $37 \mathrm{cfu}$ ) during winter, spring, summer and autumn respectively. the maximum concentration was recorded in the winter as (66 cfu ) and the minimum concentration were occurred in the summer as ( $33 \mathrm{cfu})$.

The seasonal variation of fecal Coliform count was found in the ranges $(16,11,5$ and 9 cfu) during winter, spring, summer and autumn respectively. The maximum count was occurred in the winter (16 cfu) and the minimum count was occurred in the summer ( $5 \mathrm{cfu})$.

The seasonal variation of Fecal Streptococcus count was found in the ranges of $(11,6,9$ and $11 \mathrm{cfu}$ ) during winter, spring, summer and autumn respectively. The maximum count was recorded in the winter and autumn as (11 cfu) and the minimum count were occurred in the spring ( $6 \mathrm{cfu})$.

Finally as shown in table (1). It was observed that there was inversely relationship between Turbidity and Fecal Streptococcus. Also there was directly relationship between turbidity and presence of fecal Coliform bacteria. Also there was inversely relationship between temperature and presence of bacteria.

The seasonal variation value of chemicals and biological analysis of filtrated water of (El-Arida plant) during the four seasons. It was observed that the seasonal variations in turbidity concentration of it were found in the ranges between $(1.2,1.03,0.2$ and 0.3 Nephleometric turbidity unit" NTU") during winter, spring, summer and autumn respectively. However the Highest value of Turbidity as (1.2" NTU") was detected in the winter season while the lowest value of Turbidity as ( 0.2 "NTU") was detected in the summer season. Figure (1) 
Accordingly and by Regarding the mean value of seasonal variations in temperature concentration of it water were detected in the ranges between $\left(19,26.5,29\right.$ and $\left.21{ }^{\circ} \mathrm{C}\right)$ during winter, spring, summer and autumn respectively. It was detected that the highest value at $\left(29^{\circ} \mathrm{C}\right)$ in summer season while the lowest value was detected in winter season at $\left(19.3^{\circ} \mathrm{C}\right)$.

figure (2) also showed that the mean value of seasonal variations in $\mathrm{pH}$ concentration of water was detected in the ranges between $(7.5,7.5,7.5$ and 7.5) during winter, spring, summer and autumn respectively. It was found that the $\mathrm{pH}$ value was stable in the four seasons at value of (7.5).

Analysis of network distribution of (El-Arida plant) during the four seasons.

Data presented in (table 2) showed that seasonal variation of the Total Plate Counts was found in the ranges between $(32,3,9$ and 20 "CFU") during winter, spring, summer and autumn respectively. The maximum concentration was detected in the winter ( 32 "CFU") and the minimum concentration was detected in the spring (3 "CFU").

The results in table (2) showing that the seasonal variations in turbidity concentration were detect in the ranges between $(0.5,0.72,0.64$ and $0.32 \mathrm{NTU}$ ) during winter, spring, summer and autumn respectively. The highest value of turbidity as $(0.72 \mathrm{NTU})$ was found in the spring season while the lowest value of turbidity as (0.32 NTU) was found in the autumn season.

regarding the mean value of seasonal variations in temperature degree of network distribution of water were found in the ranges between $\left(18,21,28\right.$ and $\left.20^{\circ} \mathrm{C}\right)$ during winter, spring, summer and autumn respectively. Also, it was found that the highest value as $\left(28^{\circ} \mathrm{C}\right)$ was detected in summer season while the lowest value was found in winter season as $\left(18^{\circ} \mathrm{C}\right)$.

Moreover, this table also showed the mean value of seasonal variations in $\mathrm{pH}$ concentrations of water was found in the ranges between (7.5, 7.5, 7 and 7.4) during winter, spring, summer and autumn respectively. Interestingly the maximum concentration were occurred stable in the seasons (winter and spring) at the highest value as (7.5) while the lowest value was found in summer as (7).

The seasonal variation of fecal Streptococcus count was found in the ranges $(<1,<1,<1$ and $<1 \mathrm{cfu}$ ) during winter, spring, summer and autumn respectively. The values were stable less than one $(<1)$.

Table (3) showed the mean value of chemicals and bacteriological analysis of water in (shobra-blola) plant before and after the treatment well during the four seasons. The difference between them showed that the turbidity after treatment is higher than before treatment except spring and the values of these elements ( $\mathrm{pH}$,temp, NO2, NO3, NH3, TOC,F,Mg,Ca,SO4, T DS,EC) were slightly different before and after treatment. The values of Iron $(\mathrm{Fe})$ and Manganese $(\mathrm{Mn})$ after treatment is lower than before treatment. The values of (heterotrophic, total Coliform is constant, fecal Coliform and fecal Streptococcus) bacteria after treatment were lower than before treatment.

Figure (2) Relationship between total bacterial count (A) and total Coliform bacteria(B) (before, after treatment and network distribution) seasonal variation of shobra- blola plant.

Figure (2) showing the seasonal variation value of bacteriological analysis indicators of Shobra-blola plant (before, after and network distribution water) during the four seasons. It was observed that the seasonal variations in heterotrophic bacteria ,the maximum counts were observed decrease after treatment and it increase in permissible limit in ( network distribution) .This figure illustrated that the total Coliform bacteria of four season were the maximum count before treatment and not found after treatment in the four seasons ( less than one).

Table (4) Mean value of chemicals and bacteriological analysis of water in meet -memon plant during the four seasons (direct well and network distribution) .The difference between them showed that the turbidity in direct well is higher than the network distribution except in autumn season. While the values of these elements (pH,temp,NO2,NO3,NH3,TOC,F ,Mg ,Ca,SO4,TDS,EC CaCO3,CL,AL,BOD, CU,Z, total hardness, calcium hardness and magnesium hardness ) were slightly different in direct well and network distribution. The values of Iron $(\mathrm{Fe})$ and Manganese (Mn) in direct well are higher than network distribution except autumn season. The values of (heterotrophic) bacteria in direct well was lower than before network distribution. While total Coliform bacteria is constant $(>1)$ 
except in winter (2 CFU) but fecal Coliform and Fecal Streptococcus are constant $(>1)$ in direct well and network distribution.

Species present in water during studies: This bacteria found in winter and spring seasons of network distribution system of all plants.

\section{KLUYVERA SP}

\section{ENTEROBACTER CLOACAE}

\section{E.COLI AND PROVIDENCIASTUARTII}

Comparison between normal test and rapid test for detection of indicator bacteria in drinking water.

\section{NORMAL TEST: IS DIVIDED INTO TWO TYPES:}

(Most Probable Number) MPN technical Use broth media. This use more than one media and take 7 days to obtain bacteria.

Membrane filters technical (use agar media). This use more than one media and take 4 days to obtain bacteria.

\section{RAPID TEST:}

By this test detection of the indicator bacteria to measure the quality of water will takes place in only 24 hours by using one culture media as (Lauryl tryptose broth with mug).

Table (1)Mean value of chemicals and bacteriological analysis of raw water during the four seasons inElArida plant.

\begin{tabular}{|c|c|c|c|c|c|c|}
\hline \multirow[b]{2}{*}{ Parameter } & \multirow{2}{*}{$\begin{array}{c}\text { Dec. } 458 \\
2007 \\
\text { Limits }\end{array}$} & season & winter & spring & summer & Autumn \\
\hline & & $\begin{array}{c}\text { Coordinat } \\
\text { es } \\
(\text { MSL) }\end{array}$ & raw water & raw water & raw water & raw water \\
\hline Color & Colorless & Pt/Co & colorless & colorless & colorless & Colorless \\
\hline Turbidity & $\mathbf{1}$ & NTU & 8.6 & 11 & 10 & 9 \\
\hline Temperature & - & ${ }^{\circ} \mathrm{C}$ & 19.3 & 27 & 29 & 21 \\
\hline Ph & $6.5-8.5$ & - & 7.9 & 8 & 8 & 8 \\
\hline Electric Conductivity & - & $\mu \mathrm{S} / \mathbf{c m}$ & 403.5 & 305 & 293 & 310 \\
\hline Total Dissolved Solids $\left(120^{\circ} \mathrm{C}\right)$ & 1000 & $\mathbf{m g} / \mathbf{l}$ & 201 & 154 & 146 & 212 \\
\hline Total Alkalinity as $\left(\mathrm{CaCO}_{3}\right)$ & - & $\mathbf{m g} / \mathbf{l}$ & 134.6 & 136 & 136 & 157 \\
\hline Chlorides (Cl) & 250 & $\mathbf{m g} / \mathbf{l}$ & 30.4 & 19 & 12 & 50 \\
\hline Sulfates $\left(\mathrm{SO}_{4}\right)$ & 250 & $\mathbf{m g} / \mathbf{l}$ & 39 & 28 & 17 & 45 \\
\hline Total Hardness as $\left(\mathrm{Ca} \mathrm{CO}_{3}\right)$ & 500 & $\mathrm{mg} / \mathrm{l}$ & 141.6 & 124 & 106 & 123 \\
\hline Calcium Hardness & 350 & $\mathbf{m g} / \mathbf{I}$ & 83 & 71 & 61 & 89 \\
\hline Magnesium Hardness & 150 & $\mathbf{m g} / \mathbf{l}$ & 59 & 53 & 44 & 36 \\
\hline Calcium (Ca) & - & -- & 33 & 28 & 25 & 36 \\
\hline Magnesium & - & -- & 14 & 13 & 9 & 14 \\
\hline \begin{tabular}{|l} 
Sodium \\
\end{tabular} & 2.00 & $\mathrm{mg} / \mathbf{l}$ & 30 & 22 & 24 & 25 \\
\hline Zink & 3.00 & $\mathbf{m g} / \mathbf{l}$ & ND & $\mathbf{0 . . 0 3}$ & 0.006 & 0.009 \\
\hline Cupper & 2.00 & $\mathbf{m g} / \mathbf{l}$ & ND & 0.015 & $\mathbf{0 . 0 2 2}$ & 0.046 \\
\hline Toc & - & $\mathbf{m g} / \mathbf{l}$ & 5.69 & 4.95 & 4.6 & 4.92 \\
\hline Floride & - & $\mathbf{m g} / \mathbf{l}$ & 0.27 & 0.3 & 0.33 & 0.26 \\
\hline Almonum(AL) & 0.2 & mg/l & 0.09 & 0.05 & $\mathbf{0 . 0 4}$ & 0.02 \\
\hline Ammonia as $\left(\mathrm{NH}_{3}\right)$ & 0.5 & $\mathbf{m g} / \mathbf{l}$ & 0.30 & 0.3 & 0.31 & 0.3 \\
\hline Nitrites as $\left(\mathrm{NO}_{2}\right)$ & 0.2 & $\mathbf{m g} / \mathbf{l}$ & 0.2 & 0.13 & 0.07 & 0.13 \\
\hline Nitrates as $\left(\mathrm{NO}_{3}\right)$ & 45 & $\mathbf{m g} / \mathbf{l}$ & 3.2 & 3.2 & 2.45 & 2.7 \\
\hline BOD $_{5}$ & - & $\mathbf{m g} / \mathbf{l}$ & 1.6 & o.8 & 0.7 & 1.1 \\
\hline Iron (Fe) & 0.3 & $\mathbf{m g} / \mathbf{l}$ & 0.7 & 0.6 & 0.44 & 0.45 \\
\hline Manganese (Mn) & 0.4 & $\mathbf{m g} / \mathbf{l}$ & 0.09 & 0.03 & 0.02 & 0.07 \\
\hline Total bacterial Count at $37^{\circ} \mathrm{C}$ & $>\mathbf{5 0}$ & cfu/1 ml & $\mathbf{3 1 4 8}$ & 3293 & 2712 & 2703 \\
\hline Total Coliform & $>2$ & cfu/100ml & 66 & 39 & 33 & 37 \\
\hline Fecal Coliform & -ve & cfu/100ml & 16 & 11 & 5 & 9 \\
\hline Fecal Streptococcus & -ve & cfu/100ml & 11 & 6 & 9 & 11 \\
\hline
\end{tabular}

Key: $* \mathrm{Pt} / \mathrm{Co}=$ platinum per cobalt, $* \mu \mathrm{S} / \mathrm{cm}=$ microseism per centimeter, $\quad * \mathrm{mg} / \mathrm{l}=$ mill gram per liter

$*$ cfu/ $1 \mathrm{ml}=$ colony forming unit per $1 \mathrm{ml}$ sample, *NTU =Nephleometric turbidity unit,*(- )or (ND)=not detected(zero volume) $*$ cfu/ $100 \mathrm{ml}=$ colony forming unit per $100 \mathrm{ml}$ sample, $*$ TOC=total organic carbon

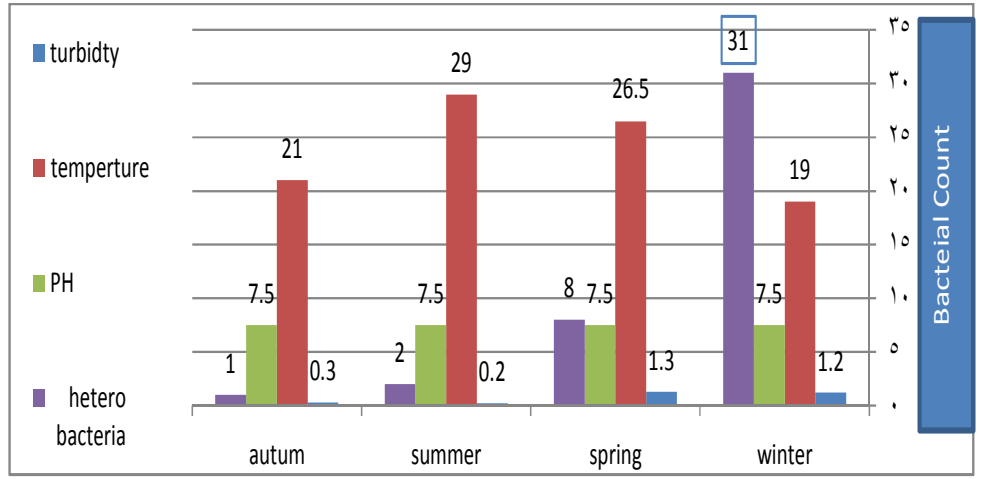

Figure (1)Showing the relationship betweenturbidity,Temperature, PH, andHeterotrophic bacteria in filtrated state of Al-Arida plant. 
Table (2) Showing the seasonal variation value of chemicals and biological Analysis of network distribution of (El-Arida plant) during the four seasons.

\begin{tabular}{|c|c|c|c|c|c|c|}
\hline \multirow[b]{2}{*}{ Parameter } & \multirow{2}{*}{$\begin{array}{l}\text { Dec. } 458 \\
\text { / 2007 } \\
\text { Limits }\end{array}$} & season & winter & Spring & summer & Autumn \\
\hline & & $\begin{array}{c}\text { Coordinate } \\
\text { s } \\
(\text { MSL })\end{array}$ & network & Network & network & network \\
\hline Color & Colorless & $\mathrm{Pt} / \mathrm{Co}$ & colorless & Colorless & colorless & colorless \\
\hline Turbidity & 1 & NTU & 0.5 & 0.72 & 0.64 & 0.32 \\
\hline Temperature & - & ${ }^{\circ} \mathbf{C}$ & 18 & 21 & 28 & 20 \\
\hline pH & $6.5-8.5$ & - & 7.5 & 7.5 & 7 & 7.4 \\
\hline Electric Conductivity & & $\mu \mathrm{S} / \mathrm{cm}$ & 423 & 380 & 351 & 333 \\
\hline $\begin{array}{c}\text { Total Dissolved Solids } \\
\left(120^{\circ} \mathrm{C}\right)\end{array}$ & 1000 & $\mathbf{m g} / \mathbf{l}$ & 216 & 191 & 188 & 235 \\
\hline $\begin{array}{c}\text { Total Alkalinity as } \\
\left(\mathrm{CaCO}_{3}\right)\end{array}$ & & $\mathrm{mg} / \mathrm{l}$ & 124 & 123 & 122 & 156 \\
\hline Chlorides (CI) & 250 & $\mathrm{mg} / \mathrm{l}$ & 37 & 24 & 19 & 53 \\
\hline Sulfates $\left(\mathrm{SO}_{4}\right)$ & 250 & mg/l & 48.5 & 39 & 27 & 53 \\
\hline $\begin{array}{c}\text { Total Hardness as (Ca } \\
\left.\mathrm{CO}_{3}\right)\end{array}$ & 500 & $\mathrm{mg} / \mathrm{l}$ & 143 & 125 & 106 & 122 \\
\hline Calcium Hardness & 350 & $\mathrm{mg} / \mathrm{l}$ & 81 & 73 & 62 & 90 \\
\hline Magnesium Hardness & 150 & $\mathrm{mg} / \mathbf{l}$ & 59 & 53 & 45 & 60 \\
\hline Calcium (Ca) & - & - & 32 & 29 & 25 & 36 \\
\hline Magnesium & - & - & 14 & 13 & 9 & 14 \\
\hline Floride & 0.8 & $\mathrm{mg} / \mathrm{l}$ & 0.26 & 0.31 & 0.25 & 0.36 \\
\hline Sodium & 2.00 & $\mathrm{mg} / \mathrm{l}$ & 35 & 29 & 26 & 20 \\
\hline Zink & 3.00 & $\mathrm{mg} / \mathrm{l}$ & ND & 0.009 & 0.005 & 0.002 \\
\hline Cupper & 2.00 & $\mathrm{mg} / \mathrm{l}$ & ND & ND & 0.014 & 0.012 \\
\hline TOC & - & - & 3.18 & 3.12 & 3 & 3.08 \\
\hline Aluminum(AL) & 0.2 & mg/l & $\mathbf{0 . 1 7}$ & 0.2 & 0.2 & 0.2 \\
\hline Ammonia as $\left(\mathrm{NH}_{3}\right)$ & 0.5 & $\mathrm{mg} / \mathrm{l}$ & 0.044 & 0.03 & 0.03 & 0.06 \\
\hline Nitrites as $\left(\mathrm{NO}_{2}\right)$ & 0.2 & $\mathrm{mg} / \mathrm{l}$ & 0.0006 & 0.005 & 0.0008 & 0.008 \\
\hline Nitrates as $\left(\mathrm{NO}_{3}\right)$ & 45 & $\mathrm{mg} / \mathrm{l}$ & 2.5 & 2.2 & 1.2 & 1.8 \\
\hline BOD $_{5}$ & - & $\mathrm{mg} / \mathrm{l}$ & $\mathbf{0}$ & $\mathbf{0}$ & $\mathbf{0}$ & 0.3 \\
\hline Iron $(\mathbf{F e})$ & 0.3 & mg/l & $\mathbf{0 . 0 3}$ & 0.04 & 0.1 & 0.003 \\
\hline Manganese (Mn) & 0.4 & $\mathrm{mg} / \mathrm{l}$ & 0.006 & 0.0003 & $\mathbf{0}$ & 0.0003 \\
\hline $\begin{array}{c}\text { Total bacterial Count } \\
\text { at } 37^{\circ} \mathrm{C} \\
\end{array}$ & $>\mathbf{5 0}$ & cfu/1 ml & 32 & 3 & 9 & 20 \\
\hline Total Coliform & $>2$ & cfu/100ml & 1 & 2 & 1 & 9 \\
\hline Fecal Coliform & -ve & cfu $/ 100 \mathrm{ml}$ & $<1$ & $<1$ & $<1$ & 2 \\
\hline Fecal Streptococcus & -ve & cfu/100ml & $<1$ & $<1$ & $<1$ & $<1$ \\
\hline
\end{tabular}

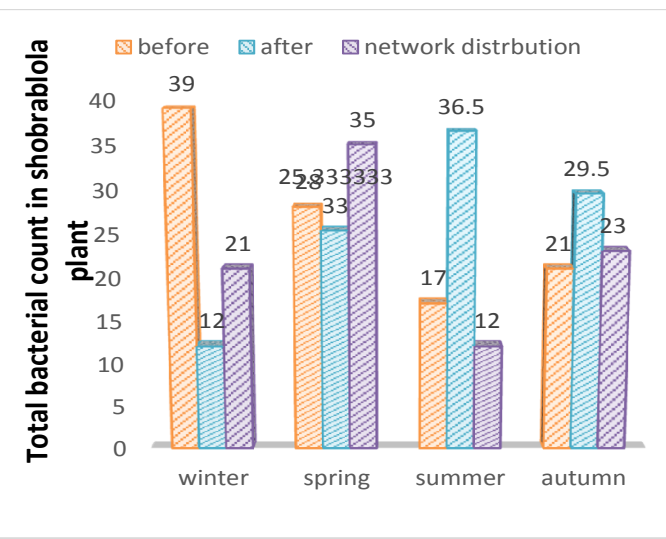

(A)

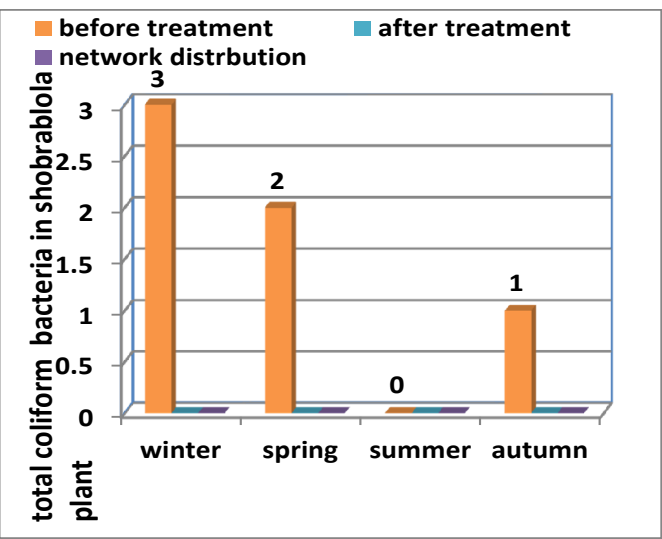

(B)

Figure (2) Relationship between total bacterial count (A) and total Coliform bacteria(B) (before, after treatment and network distribution) seasonal variationofshobra-blola plant. 
MONITORING OF DRINKING WATER QUALITY BY BACTERIAL

Table (3) Mean value of chemicals and bacteriological analysis of water in(shobra-blola) plantbefore and aftertreatment well during the four seasons.

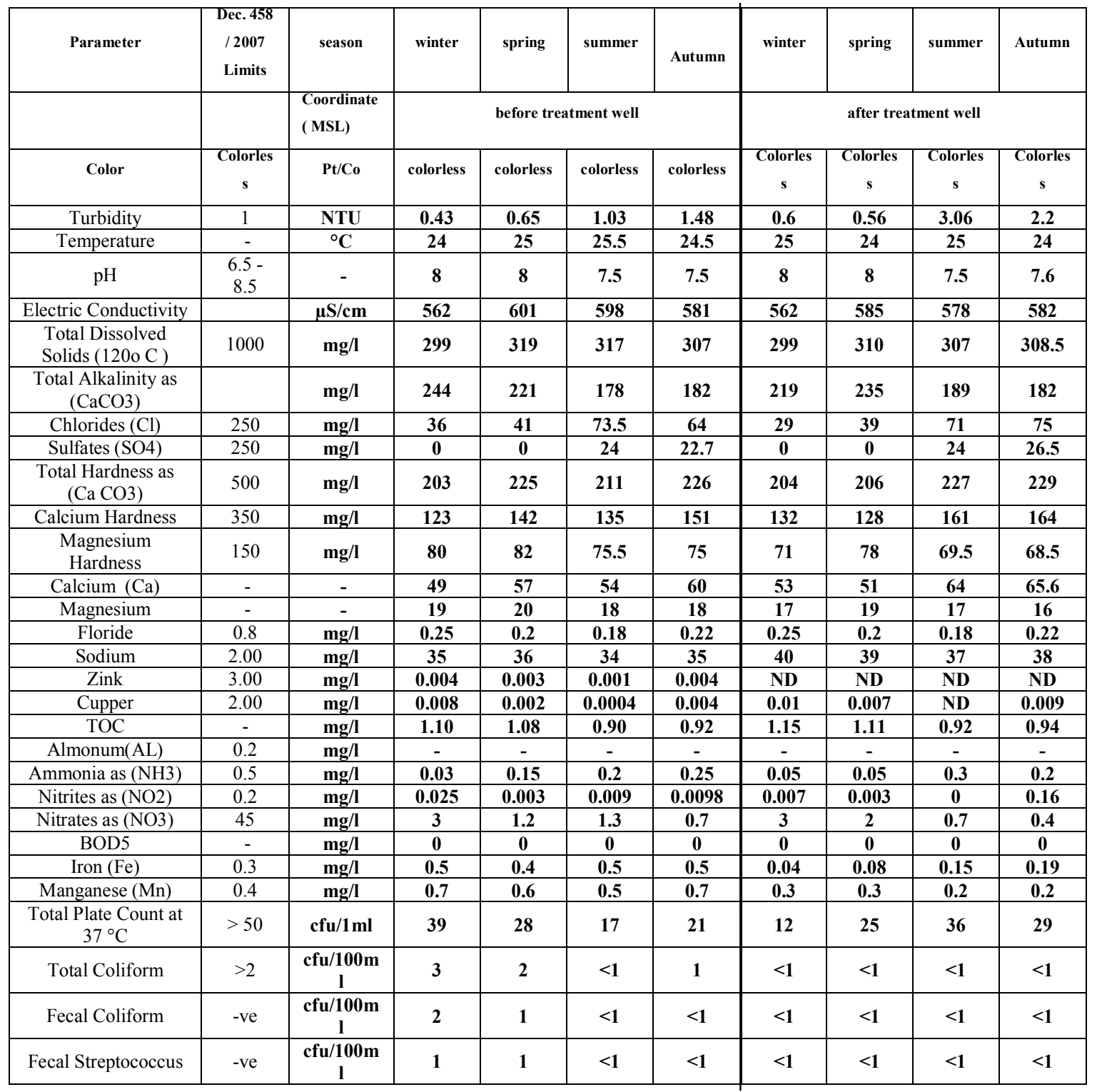


Table (4) Mean value of chemicals and bacteriological analysis of water inmeet memon plantduring the four seasons (direct well and network distribution)

\begin{tabular}{|c|c|c|c|c|c|c|c|c|c|c|}
\hline Parameter & $\begin{array}{c}\text { Dec. 458 } \\
2007 \\
\text { Limits }\end{array}$ & season & winter & spring & summer & Autumn & winter & spring & summer & Autumn \\
\hline & & $\begin{array}{l}\text { Coordinat } \\
\text { e( MSL) }\end{array}$ & \multicolumn{4}{|c|}{ direct from well } & \multicolumn{4}{|c|}{ network distribution } \\
\hline Color & $\begin{array}{c}\text { Colorles } \\
\text { s }\end{array}$ & $\mathrm{Pt} / \mathrm{Co}$ & $\begin{array}{c}\text { Colorles } \\
\text { s }\end{array}$ & $\begin{array}{c}\text { Colorles } \\
\text { s }\end{array}$ & $\begin{array}{c}\text { Colorles } \\
\text { s }\end{array}$ & $\begin{array}{c}\text { Colorles } \\
\text { s }\end{array}$ & $\begin{array}{c}\text { Colorle } \\
\text { ss }\end{array}$ & $\begin{array}{c}\text { Colorles } \\
\text { s }\end{array}$ & $\begin{array}{c}\text { Colorles } \\
\text { s }\end{array}$ & $\begin{array}{c}\text { Colorles } \\
\text { s }\end{array}$ \\
\hline Turbidity & 1 & NTU & 4.7 & 2.7 & 0.64 & 0.81 & 1.61 & 0.25 & 0.09 & 0.81 \\
\hline Electric Conductivity & & $\mu \mathrm{S} / \mathrm{cm}$ & 397 & 553.8 & 650 & 785 & 393 & 749 & 745 & 785 \\
\hline $\begin{array}{c}\text { Total Dissolved Solids } \\
(1200 \mathrm{C})\end{array}$ & 1000 & $\mathbf{m g} / \mathbf{l}$ & 196 & 287.1 & 345 & 354.5 & 367 & 397 & 395 & 354.5 \\
\hline $\begin{array}{c}\text { Total Alkalinity as } \\
\text { (CaCO3) }\end{array}$ & & $\mathbf{m g} / \mathbf{l}$ & 143 & 200 & 240 & 237.5 & 140 & 270 & 252.5 & 237.5 \\
\hline Chlorides (Cl) & 250 & $\mathrm{mg} / \mathrm{l}$ & 38 & 49.7 & 62 & 65.5 & 40 & 71 & 62.5 & 65.5 \\
\hline Magnesium Hardness & 150 & $\mathrm{mg} / \mathrm{l}$ & 83 & 92.8 & 80 & 94.5 & 88 & 108 & 92 & 94.5 \\
\hline Calcium (Ca) & - & - & 72 & 64.6 & 58.8 & 59.2 & 71 & 62.4 & 58.2 & 59.2 \\
\hline Magnesium & - & - & 33 & 29 & 19.2 & 22.68 & 35.2 & 25.92 & 22.08 & 22.68 \\
\hline Floride & 0.8 & $\mathrm{mg} / \mathrm{l}$ & 0.20 & 0.22 & 0.25 & 0.21 & 0.20 & 0.22 & 0.25 & 0.21 \\
\hline Sodium & 2.00 & $\mathrm{mg} / \mathrm{l}$ & 56 & 59 & 73 & 60 & 52 & 55 & 70 & 56 \\
\hline Zink & 3.00 & $\mathrm{mg} / \mathrm{l}$ & ND & 0.15 & ND & ND & ND & 0.17 & ND & ND \\
\hline Cupper & 2.00 & $\mathrm{mg} / \mathrm{l}$ & ND & 0.007 & ND & ND & ND & 0.009 & ND & ND \\
\hline TOC & - & $\mathrm{mg} / \mathrm{l}$ & 0.53 & 0.6 & 0.7 & 0.42 & 0.55 & 0.8 & 0.9 & 0.46 \\
\hline Almonum(AL) & 0.2 & $\mathrm{mg} / \mathrm{l}$ & 17.3 & 16 & 17.4 & 16.9 & 17.04 & 15.6 & 16.5 & 16.9 \\
\hline $\begin{array}{c}\text { Total Plate Count at } \\
37^{\circ} \mathrm{C} \\
\end{array}$ & $>\mathbf{5 0}$ & cfu/1 $\mathbf{m l}$ & 2 & 1 & 1 & 3 & 1 & $<1$ & 5 & $<1$ \\
\hline Total Coliform & $>2$ & cfu/100ml & $<1$ & $<1$ & $<1$ & $<1$ & 2 & $<1$ & $<1$ & $<1$ \\
\hline Fecal Coliform & -ve & cfu/100ml & $<1$ & $<1$ & $<1$ & $<1$ & $<1$ & $<1$ & $<1$ & $<1$ \\
\hline Fecal Streptococcus & -ve & cfu/100ml & $<1$ & $<1$ & $<1$ & $<1$ & $<1$ & $<1$ & $<1$ & $<1$ \\
\hline
\end{tabular}

Table (5)To identification the purification colony by Rapid 20e (biochemical test).

\begin{tabular}{|c|c|c|c|c|c|c|c|c|c|c|c|c|c|c|c|c|c|c|c|c|c|}
\hline organism & $\frac{0}{2}$ & $\Xi$ & $\stackrel{\circ}{\varrho}$ & 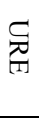 & $\exists$ & $\nabla$ & $\underset{Z}{Z}$ & $\underset{N}{\mathbb{N}}$ & $\stackrel{D}{D}$ & $\underset{ٍ}{\precsim}$ & 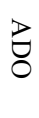 & $\underset{⿱ 乛}{\infty}$ & $\stackrel{\Omega}{M}$ & $\frac{3}{9}$ & $\begin{array}{l}n \\
B \\
\Omega\end{array}$ & 컴 & $\overrightarrow{\mathbb{Z}_{1}}$ & $\stackrel{\Omega}{\varrho}$ & 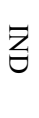 & $\lesssim$ & $\stackrel{0}{x}$ \\
\hline kluyvera sp & + & + & + & - & - & - & - & + & + & + & - & + & - & + & + & + & + & + & + & - & - \\
\hline $\begin{array}{l}\text { Enterobacter } \\
\text { cloacae }\end{array}$ & + & - & + & - & + & - & + & - & + & + & - & + & + & + & + & + & + & + & - & + & - \\
\hline E.coli & + & + & + & - & - & - & - & - & + & + & - & + & - & + & - & + & - & + & + & - & - \\
\hline $\begin{array}{l}\text { Providencia } \\
\text { stuartii }\end{array}$ & + & - & - & - & + & + & - & - & - & - & - & - & - & - & + & + & - & + & + & + & - \\
\hline
\end{tabular}




\section{DISCUSSION}

The lack of freshwater is likely to be one of the most critical natural resource issues facing people in the next 50 years. The world's population is expanding rapidly, yet our supplies of freshwater are not, placing greater demand on our water resources. However, in this study water sample were collected from El-Gharbia government from plants of El-Arida, Shobra-bolola and Meet-memon. At 21-12-2012 to 21-12-2013, these samples were subjected to bacteriological indicator, physico-chemical and chemical analysis.

The obtained results were in agreement with that obtained by Spino (1966) who studied Elevated temperature technique for the isolation of Salmonella from streams, the results showed that there was a relationship between temperatures and the survival of fecal Coliforms. These data indicate that below $15{ }^{\circ} \mathrm{C}$ survival was inversely related to temperature but above $15{ }^{\circ} \mathrm{C}$ this relationship became less critical.

Current results were also in agreement with, (Bottman, 1967) who investigated that the presence of microorganisms in groundwater is heavily dependent upon geologic conditions such as flow pathways, mechanisms, sunlight, temperature, $\mathrm{pH}$, and soil properties.

On the other hand, Heterotrophic bacteria are members of a large group of bacteria that use organic carbon for energy and growth. Many laboratories measure heterotrophic bacteria by the total plate count. However the presence of total plate count bacteria does not indicate the likelihood of pathogen presence. Also a sudden increase in total plate count bacteria may suggest a problem with treatment or water disinfection (AWWA, 1999).

Amazingly, the present study showed that there was no relationship between total plate count bacteria and the presence of pathogen. Total plate count bacteria were found also in raw water in treated well as (39 CFU ) and other bacteria were at level less than one CFU. This study clarified also that Heterotrophic bacteria was detected in too little amount in (infiltrated water, customer water and raw water in well) and the other bacteria was at level less than one CFU. Also heterotrophic bacteria was negative in customer water in well at spring and autumn. Other bacteria were also at level less than one CFU.

The present study showed also that the presence of fecal Coliform and fecal streptococcus was less than one CFU in well water as in raw and customer water.

Contrary to this study, (Washington, 2005), who studied standard methods for the examination of water and waste water determine the correlation between different bacterial indicators and the occurrence of digestive system illness at swimming beaches suggest that the best indicators of health risk from recreational water contact in fresh water are E. coli and enterococci

The present study demonstrated that there was appositive relationship between turbidity and presence of microbial community which in the same line with (Siong, C. 2001) who said that turbidity removal is positively correlated with microbial removal. When turbidity removal rate is compared to microbial removal rate, a positive relationship is identified. This shows the possibility of microorganisms to live among the suspended particles causing turbidity in water. When turbidity is reduced, the Coliform counts are also decrease accordingly and this approach is in agreement with the present results.

The present study demonstrated that four different genera were isolated and identified from some of sample sites as kluyvera sp, Enterobacter cloacae, E.coli and Providencia stuartii. It was observed that turbidity is increased with increasing the bacterial growth in raw water of El-Arida plant. On the other hand, Total bacterial count, total Coliform, fecal Coliform and fecal Streptococcus were increased in permissible limit with decrease of the turbidity network distribution. There was inversely relationship between turbidity and total bacterial count, and also between temperature and presence of bacteria in network distribution and before treatment.

As regards in the present study, it was found that there was a seasonal variation of Iron $(\mathrm{Fe})$ concentration in raw water of El-Arida and be- 
fore treatment in Shobra-blola plant. On the other hand, iron was found in permissible limit during winter, spring, summer and autumn respectively as follow: In filtrated water and network distribution of El-Arida plant in ranges between (0.01-0.03 mg/l). After treatment, iron was ranges between $(0.04-0.19 \mathrm{mg} / \mathrm{l})$ and in the network distribution, iron was ranges also between $(0.2-0.28 \mathrm{mg} / \mathrm{l})$ of Shobra-blola plant. In Meet-memone plant (direct well) iron was ranges between $(0.15-0.21 \mathrm{mg} / \mathrm{l})$ and network distribution was ranges between $(0-0.21 \mathrm{mg} / \mathrm{l})$.

Similary, Salisu , (2004) who added that the poor well casing and the effect of this can be considered as pollution of the water through rust. Although, most of the wells in the Majidun community were sited away from dump sites, the poor casing of the well, when corroded, releases reddish-brown substances (rust) into the well, and this could lead to the accumulation of heavy metals such as iron.

Furthermore, the present study presented also that there was Nitrate concentrations in three plants had low value below $4 \mathrm{mg} / \mathrm{L}$ in all sampling site.

Any way the obtained results were in accordance with that obtained by Rodríguez. , et al (2012) who studied the nitrate concentrations in surface water, and showed that low values below $4 \mathrm{mg} / \mathrm{L}$ in all sampling sites was found, while values ranged from 0.05 to $36 \mathrm{mg} / \mathrm{L}$ for drilling and between 0.32 and $37 \mathrm{mg} /$ for wells. Regarding bacterial load, the highest count of total Coliform was detected in well water and lagoon samples; however, fecal Coliform was detected in surface water and groundwater. Only significant negative correlations were found between nitrate and total Coliform and nitrate and fecal Coliform. The origin of pollution can be attributed point sources and non-agricultural activity.

The present study demonstrated also that there was magnesium concentrations in three plant with low value ranged from (9-33) $\mathrm{mg} /$ L. While the permissible level of it $(150 \mathrm{mg} / \mathrm{L})$ in all sampling site. TDS found to be increased in Shobra-blola and Meet-memone plant during autumn and summer seasons. While TDS was below in the El-Arida plant.
Bhattaraj et al. (2008), said that Magnesium concentration was below the permissible limit in all the sampling sites of his study. This approach was in agreement with the results of present study.

We can concluded from this study that : bacteriological and hydro-chemical result of the present study indicated that the sources of drinking water (coming from the Rosetta branch) in El-Gharbia governorate is divided into three sources filtrated water, treatment water and ground water.

The pollution level have been indicated as water quality index (WQI) for all annual seasons which the, arrangement of pollution level in descending order as, Winter $<$ Autumn $<$ Spring $<$ Summer. Pollution levels were the hights in winter compared to other seasons. This phenomenon may be attributed to accumulation of (wastes of drains which is accompanied by winter closer stagnant period).

The present study confirmed that there was inversely relationship between temperature and presence of bacteria in raw and in network distribution of water.

The common bacteria appears in the present study were E.coli, Enterobacter . cloacae, Providencia. stuartii and kluyvera. sp

\section{REFERENCES}

Alberta Public Health Association (APHA), Andrew, D.Eaton, Eugene, W. Rice, Arnold, E .Greenberg. (2005): Standard methods for the examination of water and wastewater. 21th ed. American Public Health Association, Washington, DC 20001-3710.

American Water Works Association (AWWA), Water Environment Federation (WEF) and Washington, D.C. (2005): standard methods for the examination of water and wastewater $21 \mathrm{~s}$ ed. American public health association.

Barry,A.L. and Badal,R.E.(1979): Rapid identification of Enterobacteriaceae with the micro-ID system versus API 20E and conventional media. J Clin Microbiol. Sep;10(3):293-298

Bhattarai, K.R., Shrestha, B. B., and Lekhak, H. D. (2008), "Water Quality of Sundarijal Reservoir and Its Feeding Streams In Kathmandu", Scientific World, Vol. 6 No. 6, 99-106.

Bottman, R. P. (1967): Microbiological and chemical studies of an open and closed watershed. J. Environ. Health. 
30:157-163. VOL 24, 1972811 on November 16, 2014 by guest.

Eissa, A.E. Tharwat, N.A. and Zaki, M.M. (2013): Field assessment of the mid winter mass kills of trophic fishes at Mariotteya stream, Egypt: chemical and biological pollution synergistic model. Chemosphere, 90: 10611068 .

Environmental Protection Agency (EPA) (1995): Report of Task Force on Guide Standard and Protocol for Testing Microbiological Water Purifiers. United States Environmental Protection Agency,CI, pp. 1-29.

Gunkel, G., J. Kosmol, M. Sobral, H. Rohn, S. Montenegro and Aureliano, J.(2007): Sugar cane industry as a source of water pollution - case study on the situation in Ipojuca River, Pernambuco, Brazil. Water, Air and Soil Pollution, 180: 261-269.

Korium, M.A. and Toufeek, M.E.F. (2008): Studies of some physicochemical characteristics of old swan Dam Reservoir and River Nile water at Aswan. Egyptian Journal of Aquatic Research, 34: 149-167.

Narasimhan,T.N.(2008):Water, law, science Journal of Hydrology, Volume349, Issues 1-2, 30 January 2008, Pages 125-138.

Nature Reviews Molecular Cell Biology 7, 861-866 (November 2006) | doi: 10.1038/nrm2021artin Chaplin1 About the author importance of water in cell biology?

Rodríguez, Silvia; Gauna, Luciana; Martínez, Gloria; Acevedo, Hugo; Romero(2012): Cesar RELACIÓN DEL NITRATO SOBRE LA CONTAMINACIÓN BACTERIANA DEL AGUA Terra Latinoamericana, vol. 30, núm. 2, abril-junio, pp. 111-119 Sociedad Mexicana de la Ciencia del Suelo, A.C. Chapingo, México.

Salisu M (2004). Evolution of biochemical parameters during composting of various wastes compost.

Siong,C.L.(2001):Appropriate Microbial Indicator Tests for Drinking Water in Developing Countries and Assessment of Ceramic Water Filters:102-105.

Spino, D. F. (1966): Elevated temperature technique for the isolation of Salmonella from streams. Appl.Microbiol. 14:591-596.

Tropical Medicine and International Health. 19, no. 8 (2014): 894 - 905. Burden of disease from inadequate water, sanitation and hygiene in low- and middle-income settings: a retrospective analysis of data from 145 countries

United Nations Children's Fund (UNICEF), UNICEF Handbook on Water Quality, 3 UN Plaza, New York, NY 10017. (2008).

United States Census Bureau Estimates. (2014): U.S. Census Bureau, International Data Base.

World Health Organization /UNICEF (2014): Joint Monitoring Programme for Water Supply and Sanitation. Pg. 14. Based on 2012 Data. Progress on Drinking Water and Sanitation, 2014 Update.

World Health Organization and UNICEF Joint Monitoring Programme (JMP). (2014). Progress on Drinking Water and Sanitation, 2014 Update

World Water Assessment Programme (WWAP). (2009): the United Nations World Water Development Report 3: Water in a Changing World. Paris: UNESCO, and London: Earthscan. 


\section{مراقبه جوده مياه الثرب بالدالائل البكتيريه ومحاولات الكشف عندها

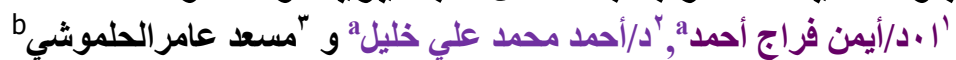

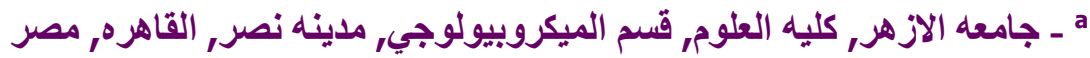

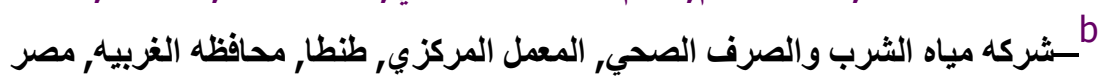

تهدف هذة الرساله الي مر اقبه جوده مياه الثرب حيث تم تجميع ثمانية عينات من المياه قبل دخول المحطات وبعد معالجتها خلال المحطه وبعد خروجها من المحطه (الثبكه)وذلك في كل من

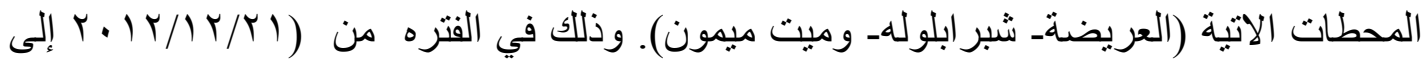

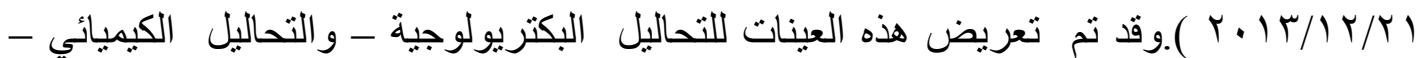
وكذلك التحاليل الفيزيائية وقد أظهرت نتائج التحاليل الكيميائية ان نسب العناصر (العسر الكلي عسر الكالسيوم وعسر الماغنسيوم)و (Ca,SO (CaCO3,CL,AL,BOD ,CU,Z, الماغنسيوم في محطه شبر ابلوله فانه يقل بعد المعالجه عن قبل المعالجه.كما أظهرت نتائج التحاليل الفزيائية ان (اللون -الئ-العكارهو درجه الحر اره) في النسب المسموح بها لمو اصفه المياه.

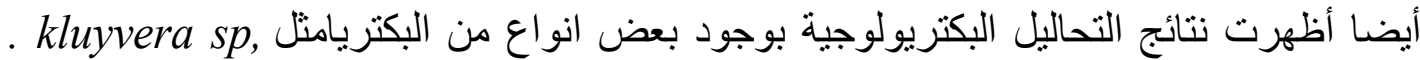
Enterobactercloacae, E.coli and Providencia stuartii ظهرت النتائج أن التحليل الكيميائي و الفيزيائي للعينات يكون عالي نسبياولكن (في النسب المسموح بها)و هذا يحدث في فصل الثتاء بسبب السده الثنتويهحيث تقل نسب المياه فيالانهار أما محاو لات الكثف عن الدلاثل البكتيريه(القلونيه الكليهـ القلونيه البرازيه) وذلك بالطرق العاديه سواء كانت بالترشيح الغشائي او العد الاكثر احتمالا فهي تستغرق خمس ايام للكثف عنها ولكن توجد طريقة أخرى نم استخدامها وهى طريقة (لوريل تربتوز بروث +mug) وقد وجد أنة باستخدام هذه الطريقه لا تستغرق سوى ك ساعه فقط للكثف عن الدائل البكترية . 